\title{
Isolation and identification of marine strains of Stenotrophomona maltophilia with high chitinolytic activity
}

\author{
Roger Salas-Ovilla ${ }^{1}$ ， Didiana Gálvez-López ${ }^{1}$ ， Alfredo Vázquez-Ovando ${ }^{1}$ ， Miguel Salvador-Figueroa ${ }^{1}$, \\ Raymundo Rosas-Quijano ${ }^{\text {Corresp. } 1}$ \\ ${ }^{1}$ Instituto de Biociencias, Universidad Autónoma de Chiapas, Tapachula, Chiapas, Mexico \\ Corresponding Author: Raymundo Rosas-Quijano \\ Email address: raymundo.rosas@unach.mx
}

Chitin is the second most abundant organic compound in nature and represents a rich carbon and nitrogen source that is primarily transformed by bacterial communities. Bacteria capable of gradually hydrolyzing chitin into $\mathrm{N}$-acetylglucosamine monomers can have applications in the transformation of residues from shrimp and other crustaceans. The objective of the present study was to isolate, characterize and identify microorganisms with high chitinolytic activity. These microorganisms were isolated and characterized based on macro- and microscopic morphological traits. Strains were selected on colloidal chitin agar medium primarily based on a hydrolysis halo larger than $2 \mathrm{~mm}$ and a growing phase no longer than 6 days. Secondary selection consisted of semi-quantitative evaluation of chitinolytic activity with a drop dilution assay. From the above, ten strains were selected. Then, strain-specific activity was evaluated. The B4 strain showed the highest specific activity, which was $6,677.07 \mathrm{U} / \mathrm{mg}$ protein. Molecular identification indicated that the isolated strains belong to the species Stenotrophomonas maltophilia. 


\section{Isolation and identification of marine strains of Stenotrophomona maltophilia with high chitinolytic activity \\ Short title: Marine chitinolytic strains}

\section{Roger Salas-Ovilla, Didiana Gálvez-López, Alfredo Vázquez-Ovando, Miguel Salvador-} Figueroa, Raymundo Rosas-Quijano*

Instituto de Biociencias, Universidad Autónoma de Chiapas. Tapachula, Chiapas, México. *Corresponding author: raymundo.rosas@unach.mx

\section{Abstract}

Chitin is the second most abundant organic compound in nature and represents a rich carbon and nitrogen source that is primarily transformed by bacterial communities. Bacteria capable of gradually hydrolyzing chitin into $\mathrm{N}$-acetylglucosamine monomers can have applications in the transformation of residues from shrimp and other crustaceans. The objective of the present study was to isolate, characterize and identify microorganisms with high chitinolytic activity. These microorganisms were isolated and characterized based on macro- and microscopic morphological traits. Strains were selected on colloidal chitin agar medium primarily based on a hydrolysis halo larger than $2 \mathrm{~mm}$ and a growing phase no longer than 6 days. Secondary selection consisted of semi-quantitative evaluation of chitinolytic activity with a drop dilution assay. From the above, ten strains were selected. Then, strain-specific activity was evaluated. The B4 strain showed the highest specific activity, which was $6,677.07 \mathrm{U} / \mathrm{mg}$ protein. Molecular identification indicated that the isolated strains belong to the species Stenotrophomonas maltophilia.

Key words: Chitinolytic strains, chitinases, specific activity, seawater, shrimp residues.

\section{Introduction}

Shrimp production in Latin America was estimated to be between 500,000 and 600,000 tons in 2016, with Mexico being one of the main suppliers (FAO, 2016). Although the commercialization of this crustacean generated an economic revenue of more than 16 million pesos in 2016, the residues generated by the shrimp industry have a negative impact on the environment (SIAP, 2016). Of these residues, approximately 5\% is transformed into products such as flours and extracts, which serve as a base for animal feed (Laxman et al, 2016). Shrimp rubbish containing 
$3240 \%$ chitin, which is a polysaccharide composed of $\mathrm{N}$-acetylglucosamine units (Younes and 33 Rinaudo, 2015), represents an important primary resource for the production of bioactive molecules (Gao et al, 2016). Currently, there are two pathways for the production of chitin oligosaccharides: the chemical pathway and the biotechnological pathway. Although the most commonly used is the chemical pathway, it has negative implications: the cost of processing and the damage to the environment by highly corrosive chemical reagents (Kaur and Singh, 2013; Abirami et al, 2016). In contrast, the biotechnological pathway is an environmentally friendly process (Pal et al, 2014). In this context, the use of chitinases plays a key role (Wang et al, 2016). Chitinases are glycosyl-hydrolase proteins (EC 3.2.2.14) that cleave the $\beta-1,4$ bonds of the Nacetylglucosamine units, catalyzing chitin degradation (Deeba et al, 2016). Chitinolytic enzymes are synthesized in a wide variety of organisms, with fungi and bacteria being the most common. Although the chitinolytic activity of some species has been reported in the literature, it remains unknown which group of microorganisms is the most effective at decomposing this polymer. Several authors have reported marine ecosystems as a main source of chitinase-producing microorganisms, mainly bacteria (Sara et al, 2016; Swiontek et al, 2014; Suresh, 2012). Chitinolytic bacteria represent only $4 \%$ of the currently known bacteria (Swiontek et al, 2014). There are reports about chitin being degraded in aquatic environments by bacteria of the genera Aeromonas, Enterobacter, Chromobacterium, Arthrobacter, Flavobacterium, Serratia, Bacillus, Erwinia, and Vibrio (Souza et al, 2011). Other studies have isolated genera such as Eubacterium, Streptococcus and Clostridium from whale residues (Olsen et al, 2000); the species Bacillus licheniformis from food industry liquid residues (Laribi-Habchi et al, 2015); other genera such as Serratia and Streptomyces from crustacean residues (Castro et al, 2011); and the species Acinetobacter johnsonii and Bacillus amyloliquefaciens from shrimp residues (Imanda and Suharjono, 2015). However, the isolation of chitinolytic microorganisms in marine environments has been rare in comparison to the isolation of such microorganisms from terrestrial environments, due the most of reported chitinolitic microorganisms are aerobics (Swiontek et al, 2014). Therefore, the objective of the present study was to isolate and identify chitinolytic bacteria from shrimp residues and sea water.

\section{Materials and Methods}

\section{Sample collection}


63 Two kinds of samples were collected: the first consisted of $100 \mathrm{~g}$ of shrimp rubbish, and the second

64

65

66

67

68

69

70

71

72 consisted of 6 samples of $200 \mathrm{ml}$ of sea water from the sediment-free surface in different sectors of Las Escolleras-Puerto Madero in Chiapas, Mexico (latitude 14² $2^{\prime} 19^{\prime \prime} \mathrm{N}$ and longitude $\left.92^{\circ} 24^{\prime} 28^{\prime \prime} \mathrm{W}\right)$. The samples were aseptically collected in a hermetically sealed sterile cover and transported on ice container to the laboratory of the Biosciences Institute at Chiapas Autonomous University, where they were processed immediately.

\section{Colloidal chitin preparation}

Colloidal chitin was prepared according with Arnold and Solomon (1986) as follows: $10 \mathrm{~g}$ of commercial chitin from shrimp crust (Sigma-Aldrich, USA) was mixed with $100 \mathrm{ml}$ of concentrated $\mathrm{HCl}$ and stored at $4^{\circ} \mathrm{C}$ for $24 \mathrm{~h}$. Then, $100 \mathrm{ml}$ of distilled water was added, and the mixture was allowed to rest for 5 min. The chitin solution was then filtered with Whatman ${ }^{\mathrm{TM}}$ No. 1 paper, and the sediment was rinsed three times with distilled water. The chitin sediment was stored in a flask at $4^{\circ} \mathrm{C}$ for later use.

\section{Isolation of chitinolytic microorganisms}

The samples were inoculated in serial dilutions by dispersion in the semisynthetic media composed by $(\mathrm{g} / \mathrm{l}): \mathrm{Na}_{2} \mathrm{HPO}_{4}, 6.0 ; \mathrm{KH}_{2} \mathrm{PO}_{4}, 3.0 ; \mathrm{NH}_{4} \mathrm{Cl}, 1.0 ; \mathrm{NaCl}, 0.5 ;$ yeast extract, 0.05; agar, 15; colloidal chitin, 10 and $\mathrm{pH} 7$ (Shivalee et al, 2016). All the reagents used were of analytical grade. Petri dishes were incubated at $30^{\circ} \mathrm{C}$ for $4-5$ days, and growth was checked daily. Microorganism colonies that grew were selected. Then, the chitinolytic activity was confirmed by the formation of a hydrolysis halo. The colonies' purity was confirmed by reinoculation onto colloidal chitin agar medium.

\section{Selection of chitinolytic bacteria}

The primary isolation consisted of selecting the strains with the highest chitinolytic activity using the growing time of the colony and the hydrolysis halo size ( $2 \mathrm{~mm}$ at minimum) as parameters. For this purpose, the strains were inoculated onto colloidal chitin agar $(3 \%)$ and incubated at $30^{\circ} \mathrm{C}$ for 5 days. From this selection, a semi-quantitative assay was performed via a drop assay in colloidal chitin medium in the following manner: the primary isolates were inoculated in $2 \mathrm{ml}$ Eppendorf tubes containing $1 \mathrm{ml}$ of liquid colloidal chitin medium and incubated at $150 \mathrm{rpm}$ at 
$9430^{\circ} \mathrm{C}$ for 3 days. Then, serial dilutions were made from each tube in saline solution $(0.8 \% \mathrm{p} / \mathrm{v})$, 95 and the $10^{-6}, 10^{-7}$ and $10^{-8}$ dilutions were selected and inoculated in duplicate.

96

97

98

99

100

101

102

103

104

105

106

107

108

109

110

111

112

113

114

115

116

117

118

119

120

121

122

123

124

\section{Determination of specific chitinolytic activity}

Chitinolytic activity was determined according to the method proposed by Chakrabortty et al. (2012). For this, all strains were cultured during five days in the semisynthetic broth media. After, supernatants from the respective cultures were obtained by centrifugation at $2600 \mathrm{rcf}$ for $5 \mathrm{~min}$. The individual reaction mixture consisted of $1 \mathrm{ml}$ of individual culture supernatants, $1 \mathrm{ml}$ of $1 \%$ (w/v) colloidal chitin in citrate phosphate buffer $\mathrm{pH} 5.5$ and incubated at $50{ }^{\circ} \mathrm{C}$ for $30 \mathrm{~min}$. Following incubation, all the reaction mixtures were put in boiling water bath for 3 min to stop the enzyme action. The solutions were centrifuged at $2600 \mathrm{rcf}$ for $10 \mathrm{~min}$. The amount of reducing sugar in the supernatants (resulting due the chitinolytic activity) was determined by dinitrosalycilic acid (DNS) method. The absorbance was read at $540 \mathrm{~nm}$ using a UV-VIS spectrophotometer (SANYO Gallenkemp, Germany). To estimate the amount of protein, the Lowry method was used (Lowry et al, 1951). One enzymatic unit was defined as the amount of enzyme that produced 1 $\mu \mathrm{mol}$ of N-acetyl-D-glucosamine per minute.

\section{Molecular identification of microorganisms}

For identification, it was necessary to obtain the genomic DNA of the microorganisms. The strains were grown in $15 \mathrm{ml}$ Falcon tubes with $5 \mathrm{ml}$ of colloidal chitin medium and incubated at $150 \mathrm{rpm}$ for 3 days at room temperature. Then, $1 \mathrm{ml}$ of each cell culture was transferred to $1 \mathrm{ml}$ sterile Eppendorf tubes, which were then centrifuged at 15,000 $\mathrm{rcf}$ for $5 \mathrm{~min}$. The supernatant was discarded, and the cell pellet was rinsed three times with 1,000 $\mu$ of $\mathrm{NaCl}$-EDTA $(30 \mathrm{mM} \mathrm{NaCl}$, $2 \mathrm{mM}$ EDTA, $\mathrm{pH}$ 8.0) and then stored at $4^{\circ} \mathrm{C}$ for later processing. The gDNA was extracted according to the method reported by Sachinandan et al (2010) and was then quantified and stored. Then, a 16S ribosomal subunit gene fragment was amplified following the procedures described by Setia and Suhurjono (Imanda and Suharjono, 2015). The purified amplicons were sent to the Institute of Biotechnology of UNAM in Mexico for Sanger sequencing. The sequences were visualized and aligned in BioEdit v.7.0.5 software, and a phylogenetic tree was constructed in MEGA v.7.0.26 software. The evolutionary distance was calculated using 1,000 bootstrap replicates. 
126 Statistical Analysis

127 Analysis of variance (ANOVA) was performed on the specific chitinolytic activity data using the

128 statistical software InfoStat v.11.7. Means were compared using Tukey tests $(\mathrm{P} \leq 0.05)$.

\section{Results}

131

132

133

134

135

136

137

138

139

140

141

142

143

144

145

146

147

148

149

150

151

152

153

154

More than 200 colony-forming units (CFUs) from chitinolytic microorganisms were isolated (approximately 65\% from solid residues and 35\% from water), which presented mainly a yellow and white coloration. However, there were colonies with intense yellow and violet colorations, and some had dusty characteristics and the presence of mycelia. Then, the number of strains was reduced to 20 based on the colonial morphology criteria, and these colonies were purified. Through the selection procedure described in the Materials and Methods section, the number was reduced to 10 strains.

The strains B2, B3, B5, B8, B9 and B10 were isolated from shrimp shells, and the strains B1, B4, B6 and B7 were isolated from seawater. Most of the bacterial colonies presented similar macroscopic characteristics: circular shape, full borders, convex and smooth texture and whiteyellow coloration. The 10 selected strains were Gram negative, bacillus shaped, individual and lightly curved.

The 10 strains expressed different hydrolysis halo sizes (Fig. 1). This is indicative of the isolated and selected organisms being different, even if they share morphological traits. Among the strains, the B4 strain showed the largest hydrolysis halo after 4 days of growth $(0.9 \mathrm{~mm})$.

\section{Specific chitinolytic activity}

The results from the analysis of chitinolytic activity are shown in Fig. 2. These results indicated that the 10 selected strains have different capacities to hydrolyze chitin. The significant differences $(\mathrm{P}<0.05)$ in the chitinolytic activity of the strains allowed the strains to be organized into three groups (Fig. 2). The first group was formed by the strains B2, B3, B8, B9 and B10, which presented the lowest specific activity; the second group was formed by the strains B1 and B6, which presented moderate activity; and the third group was formed by the strains B4, B5 and B7, which presented the highest specific activity. 
155 The results of the specific activity test showed that the specific activity of the selected strains 156 ranged from $1,593.87 \mathrm{U} / \mathrm{mg}$ to $6,677.07 \mathrm{U} / \mathrm{mg}$ of protein. In general, it was observed that there 157 was a direct correlation between the observed specific activity and the formation of the hydrolysis 158 halo in the plaque observed for each strain.

159

160

161

162

\section{Amplification and sequencing of the $16 \mathrm{~S}$ ribosomal subunit gene}

When compared to sequences in the database, the sequences of the amplicons from strains B1 through B9 showed 99\% identity with Stenotrophomonas maltophilia. The exact B10 strain

163

164

165

166

167

168

169

170

171

172

173

174

175

176

177

178

179

180

181

182

183

184

sequence was unclear according to the analysis of the electropherogram, most likely because B10 was not a pure strain. To strengthen the identification of the strains, the phylogenetic relationship of the $16 \mathrm{~S}$ ribosomal subunit gene of the strains in this study with the genera reported in the NCBI database was determined. The phylogenetic tree shown in Fig. 3 confirmed the identification of the bacterial strains as Stenotrophomonas maltophilia. Upon analyzing the strains in the database, it was observed that among the same species, there was genetic diversity, with 4 distinct groups. Most of the strains from this study are classified in group I, and the others are in groups II and III; none are in the largest group, group IV. On the other hand, the external reference strains (K-12, KT2440 and NC7401) were grouped in a distant branch of the genus Stenotrophomonas. This confirms that the strains isolated in this study are $S$. maltophilia.

\section{Discussion}

This research reports the isolation and molecular identification of 10 strains, all belonging to the genus Stenotrophomonas maltophilia with unusual chitinolytic activity, from a marine environment, shortly explored. The number of isolates obtained in this study was similar to that reported by Lilja (2013), who isolated more than 300 strains with chitinolytic activity from marine sources. Additionally, that author concluded that the types of samples, the treatment of the samples and the nutrimental composition of the culture media are critical factors that strongly influence the number of organisms obtained. This is due to the distribution of bacterial populations not being homogeneous in the samples and each organism having different nutritional requirements. Rashad et al. (2015) reported that shrimp samples tend to have a larger number of bacterial colonies $(60 \%$ of the isolates), which aligns with what was found in this study. Even the percentage was 
185 maintained in the organisms with higher chitinolytic capacity. Chitin as a carbon and nitrogen 186 source requires transformation by enzymes called chitinases into shorter oligomers that can be 187 absorbed by microorganisms. The appearance of a halo surrounding the strains is indicative of 188 chitinase activity. Previous studies have indicated that halo appearance requires a long incubation 189 time between 5 and 6 days (Cody, 1989). The presence and isolation of Gram-negative bacteria is 190 common in marine samples, especially shrimp residues. Gram-negative bacteria are the cause of 191 diseases in crustaceans, which mainly attack the cuticle of these organisms (Sharmila et al, 2014). 192 Vincy et al. (2014) isolated marine bacteria that formed dull, creamy yellow colonies and were 193 Gram-negative and bacillus-shaped. On the other hand, Das et al. (2006) indicated that Gram194 negative microorganisms have certain traits, such as tolerance to extreme temperature and rapid 195 adaptation to different salt concentrations and nutrient deficiencies that allow them to survive in 196 the marine environment. Therefore, the diversity of Gram-negative bacteria in marine 197 environments is extremely high (90\%) compared to that of Gram-positive bacteria (Nocker et al, 2004). This is the possible reason why all the selected bacteria where Gram negative.

With respect to the specific enzymatic activity found, the 10 strains showed values higher than those reported by Kim-Chi et al. (2011), who determined a maximum specific enzymatic activity of $18.33 \mathrm{U} / \mathrm{mg}$ of protein in a strain of Streptomyces sp. On the other hand, Swiontek and Donderski (2006) obtained specific chitinolytic activity values of $0.12 \mathrm{U} / \mathrm{mg}$ of protein, which is lower than the values obtained in this study. In Bacillus sp. bacteria, the strain Hul showed in crude extract an activity of $11.1 \mathrm{U} / \mathrm{mg}$ of protein (Dai et al, 2011), whereas another chitinolytic enzyme from $B$. licheniformis strain LHH100 showed a value of 494.5 U/mg of protein (LaribiHabchi et al, 2015). Finally, Amar et al. (2017) studied the specific activity of a chitinase in Bacillus sp. strain R2 and found $234.1 \mathrm{U} / \mathrm{mg}$ of protein as the highest value for that strain. These findings indicate that the strains isolated and selected in this study have a strong chitinolytic capacity. However, the chitinolytic activity found in the present study is lower than that of the enzymes found by Liang et al. (2013) in B. cereus with specific activities of $16,598 \mathrm{U} / \mathrm{mg}$ of protein.

214 The taxonomic classification of $S$. maltophilia was described recently when Palleroni and 215 Bradbury (1993) proposed the creation of a new genus denominated Stenotrophomonas ("Stenos", 
216 from the Greek word for narrow; "trophos", from the Greek word for food; and "monas", from the

217 Greek word for unique or unity; thus, the name translates into "low substrates for food". In the 218 species name of S. maltophilia, "malt" is derived from the English word "maltose", and "philia" 219 is derived from the Greek word for friendship, that includes 10 species. These species are 220 colonizers, which enables their isolation from diverse sources, such as water, sediment, soil, the 221 rhizosphere, and plant tissues. However, there is scarce information about marine samples, and 222 some authors report that $S$. maltophilia does not withstand extreme salinity levels, suggesting that 223 it is not possible to isolate it from marine environments (Kielak et al, 2013; Zhu et al, 2011). Such 224 reports are very relevant to this study, since the frequency of this microorganism in the isolates 225 was almost $100 \%$. This high frequency can be attributed to the microorganism's high capacity to 226 break down chitin as its carbon source and to its ability to displace other species during selection. 227 Another factor to consider is that the pollution in the places from which the samples were taken 228 could have influenced the presence of this microorganism. Contamination from the extensive release of organic residues by the industry, the accumulation of decomposing organisms, the presence of hydrocarbons from the use of fuels, and the presence of agrochemicals create favorable conditions for the growth of $S$. maltophilia. According to some reports, S. maltophilia is frequently present in environments polluted with hydrocarbons, pesticides and heavy metals, and its isolation is possible from these locations (Alfonso et al, 2016; Mukherjee and Roy, 2016; Ozdal et al, 2017). The identification, sequencing or use of the genetic material of these microorganisms could represent a biotechnological alternative to develop nonpathogenic microorganisms capable of degrading chitin.

\section{Conclusion}

More than 200 CFUs from bacteria with chitinolytic potential were isolated, from which 10 strains presented the desired traits regarding chitin degradation. Through molecular analysis of the 10 selected strains, it was determined that 9 belong to the species Stenotrophomonas maltophilia. The strain with the highest chitinolytic capacity was B4, with a specific activity of $6,677 \mathrm{U} / \mathrm{mg}$ of protein. The strains from Stenotrophomonas maltophilia identified in this study are excellent producers of chitinases, and the sequences chitin genes could be identified, sequenced, or used by heterologous gene expression purposes. 


\section{Conflicts of interest}

248 The authors declare no conflicts of interest.

249

250

\section{Acknowledgements}

251 The authors are grateful to the Mexican project SEP-PRODEP DSA/103.5/16/14474 for financial 252 assistance and for the scholarship granted. Additionally, they are grateful to the project 253 CONACYT INFRA-2015-01-254256 for financing the infrastructure used in the development of 254 this study.

255

256

\section{References}

257

258

259

260

261

Abirami S, Yogalsakshmi K, Raja PAS, Kananan M. 2016. Screening and identification of chitin degrading bacteria from shrimpshell waste dumping soil environment and its media optimization for chitinase enzyme production. World Journal of Pharmacy and Pharmaceutical Sciences. 5(11):743-757. DOI 10.20959/wjpps201611-7713.

262

263

264

265

266

Alfonso GG, Cristiani UE, Mateo FC, Peralta H, Cancino DJ, Cruz MJA, Roblero JJ. 2016. Stenotrophomonas maltophilia isolated from gasolina-contaminated soil is capable of degrading methyl tert-butyl ether. Electronic Journal of Biotechnology. 23:12-20. DOI 10.1016/j.ejbt.2016.06.006.

267

268

Amar CB, Ibrahim ZT, Rafik EL-Mahdy, Hisham EL-Massry. 2017. Effect of carbon sources on Bacillus sp. R2 chitinase production. Advances in Environmental Biology. 11(3):75-80.

Arnold LD, Solomon NA. 1986. Manual of industrial mycrobiology and biotechnology. American Society for Microbiology, Washington. 
274 Castro R, Álvarez A, Machado E, Mendoza M, Gómez R, García P. 2011. Caracterización de 275 una quitinasa extracelular producida por Serratia sp. BIOMI-363706 usando quitina coloidal 276 como sustrato. Revista de la Sociedad Química del Perú. 77(2):101-108.

277

278

279

280

Chakrabortty S, Bhattacharya S, Das A. 2012. Optimization of process parameters for chitinase production by a marine isolate of Serratia marcescens. International Journal of Pharma and Bio Sciences. 2(2):08-20.

281

282

Cody MR. 1989. Distribution of chitinase and chitobiase in Bacillus. Current Microbiology. 19:201-205.

284

285

286

287

Dai HD, Hu LW, Huang RG, Li W. 2011. Purification and characterization of a novel extracellular chitinase from thermophilic Bacillus sp. Hu1. African Journal of Biotechnology. 10(13):2476-2485. DOI 10.5897/AJB10.1029

288

289

Das S, Lyla PS, Khan SA. 2006. Marine microbial diversity and ecology: importance and future perspectives. Current Science. 90(10):1325-1335.

291

292

Deeba F, Abdullah SH, Irfan M, Iqbal QJ. 2016. Chitinase production in organisms: a review. 293 Punjab University Journal of Zoology. 31(1):101-106.

294

295

FAO. 2016. Available at http://www.fao.org/in-action/globefish/market-reports/resource296 detail/en/c/989543/ (accessed 16 December 2017). 
298

299

300

301

302

303

304

305

306

307

308

309

310

311

312

313

314

315

316

317

318

319

320

321

Gao X, Chen X, Zhang J, Guo W, Jin F, Yan N. 2016. Transformation of chitin and waste shrimp shells into acetic acid and pyrrole. ACS Sustainable Chemistry England. 4:3912-3920. DOI 10.1021/acssuschemeng.6b00767.

Imanda NS, Suharjono. 2015. Chitinolytic assay and identification of bacteria isolated from shrimp waste based on 16S rDNA sequences. Advances in Microbiology. 5:541-548. DOI 10.4236/aim.2015.57056.

Kaur S, Singh DG. 2013. Recent trends in biological extraction of chitin from marine shell wastes: a review. Critical Reviews in Biotechnology. 1-18. DOI $10.3109 / 07388551.2013 .798256$.

Kielak MA, Silvia CM, Semenov VA, Sørensen JS, Van EJD. 2013. Bacterial chitinolytic communities respond to chitin and $\mathrm{pH}$ alteration in soil. Applied and Environmental Microbiology. 79(1):263-272. DOI 10.1128/AEM.02546-12.

Kim-Chi H, Tzu HL, Chung SL, Tsong YC, Yi CL. 2011. The chitinolytic activities of Streptomyces sp. TH-11. International Journal of Molecular Sciences. 12:56-65. DOI $10.3390 /$ ijms 12010056.

322 
323

324

325

326

327

328

329

330

331

332

333

334

335

336

337

338

339

340

341

342

343

344

345

346

347
Laxman VP, Guemiza K, Rouissi T, Jyoti SS, Kaur BS. 2016. Novel biological and chemical methods of chitin extraction from crustacean waste using saline water. Journal of Chemistry Technology and Biotechnology. 91:2331-2339. DOI 10.1002/jctb.4821.

Liang WT, Hsieh YT, Wang LS. 2013. Purification of a thermostable chitinase from Bacillus cereus by chitin affinity and its application in microbial community changes in soil. Bioprocess and Biosystems Engineering. 37(6):1-9. DOI 10.1007/s00449-013-1092-2.

Lilja T. 2013. Isolating microorganisms from marine and marine-associated samples. Thesis, Swedish University of Agricultural Sciences.

Lowry OH, Rosebrough NJ, Farr AL, Randall RJ. 1951. Protein estimation with the folin phenol reagent. Journal of Biological Chemistry. 193(1):265-275.

Mukherjee P, Roy P. 2016. Genomic potential of Stenotrophomonas maltophilia in bioremediation with an assessment of its multifaceted role in our environment. Frontiers in Microbiology. 7(967):1-14. DOI 10.3389/fmicb.2016.00967.

Nocker A, Lepo EJ, Snyder AR. 2004. Influence of an oyster reef on development of the microbial heterotrophic community of an estuarine biofilm. Applied and Environmental Microbiology. 70:6834-6845. DOI 10.1128/AEM.70.11.6834-6845.2004.

Olsen AM, Blix SA, Utsi THA, Sørmo W, Mathiesen DS. 2000. Chitinolytic bacteria in the minke whale forestomach. Canadian Journal of Microbiology. 46:85-94. DOI 10.1139/w99112. 
Ozdal M, Gur OO, Faruk AO, Basaran KE. 2017. Biodegradation of $\alpha$-endosulfan via hydrolysis pathway by Stenotrophomonas maltophilia OG2. 3 Biotech. 7(113):1-7. DOI 10.1007/s13205-017-0765-y.

Pal J, Om VH, Kumar MV, Kumar MS, Roy D, Kumar J. 2014. Biological method of chitin extraction from shrimp waste an eco-friendly low cost technology and its advanced application. International Journal of Fisheries and Aquatic Studies. 1(6):104-107.

Palleroni JN, Bradbury FJ. 1993. Stenotrophomonas, a new bacterial genus for Maltophilia (Hugh 1980) Swings et al. Xanthornonas 1983. International Journal of Systematic Bacteriology. 43(3):606-609. DOI 10.1099/00207713-43-3-606.

Rashad FM, Hayam MF, Ayatolla S, El-Zayat, Ahlam ME. 2015. Isolation and characterization of multifunctional Streptomyces species with antimicrobial, nematicidal and phytohormone activities from marine environments in Egypt. Microbiological Research. 175:34-47. DOI 10.1016/j.micres.2015.03.002.

Sachinandan D, Gurpreet K, Amit R, Gaurav D, Ramakant K, Paras Y, Rameshwar S, Tirtha KD, Surender LG. 2010. A simple method for the efficient isolation of genomic DNA from Lactobacilli isolated from traditional indian fermented milk (dahi). Indian Journal of Microbiology. 50(4):412-418. DOI 10.1007/s12088-011-0079-4.

Sara SP, Andersen B, Gram L, Machado H. 2016. Biological potential of chitinolytic marine bacteria. Marine Drugs. 14:1-17. DOI 10.3390/md14120230. 
374 Sharmila FRJ, Latha NP, Ravichandran ARS, Devi S, Sivasubramanian K. 2014. Shell disease

375 in the freshwater crab, Barytelphusa cunicularis. International Journal of Fisheries and Aquatic 376 Studies. 1(3):105-110.

377

378

379

380

381

382

SIAP.

2016.

Available

at

383

http://www.campomexicano.gob.mx/raw_pesca_gobmx/seccionar_especie.php (accessed 16 December 2017).

385

386

387

388

389

390

391

392

Souza PC, Almeida CB, Colwell RR, Rivera GN. 2011. The importance of chitin in the marine environment. Marine Biotechnology. 13:823-830. DOI 10.1007/s10126-011-9388-1.

393

394

395

Suresh VP. 2012. Biodegradation of shrimp processing bio-waste and concomitant production of chitinase enzyme and N-acetyl-D-glucosamine by marine bacteria: production and process optimization. World Journal of Microbiology and Biotechnology. 28:2945-2962. DOI 10.1007/s11274-012-1106-2.

396

397

Swiontek BM, Jankiewicz U, Burkowska A, Walczak M. 2014. Chitinolytic microorganisms

398

399

and their possible application in environmental protection. Current Microbiology. 68:71-81. DOI 10.1007/s00284-013-0440-4.

400 
401 Vincy V, Vinu SM, Viveka S, Mary VT, Jasmin BRJ. 2014. Isolation and characterization of 402 chitinase from bacteria of shrimp pond. European Journal of Experimental Biology. 4(3):78$403 \quad 82$.

404

405 Wang Y, Song Q, Zhang Xiao-Hua. 2016. Marine microbiological enzymes: studies with 406 multiple strategies and prospects. Marine Drugs. 14:1-23. DOI 10.3390/md14100171.

407

408 Younes I, Rinaudo M. 2015. Chitin and chitosan preparation from marine sources. Structure, 409 properties and applications. Marine Drugs. 13:1133-1174. DOI 10.3390/md13031133.

410

411 Zhu B, Liu H, Wen-Xiao T, Xiao-Ying F, Li B, Xue-Ping Z, Gu-Lei J, Guan-Lin X. 2011.

412 Genome sequence of Stenotrophomonas maltophilia RR-10, isolated as an endophyte from 413 rice root. Journal of Bacteriology. 194(5):1280-1281. DOI 10.1128/JB.06702-11 


\section{Figure 1}

Hydrolysis halos in colloidal chitin agar medium of the strains selected by drop dilution assay.

the brown squares show the 10 selected strains, whereas the white squares show the nonselected strains.

*Note: Auto Gamma Correction was used for the image. This only affects the reviewing manuscript. See original source image if needed for review.

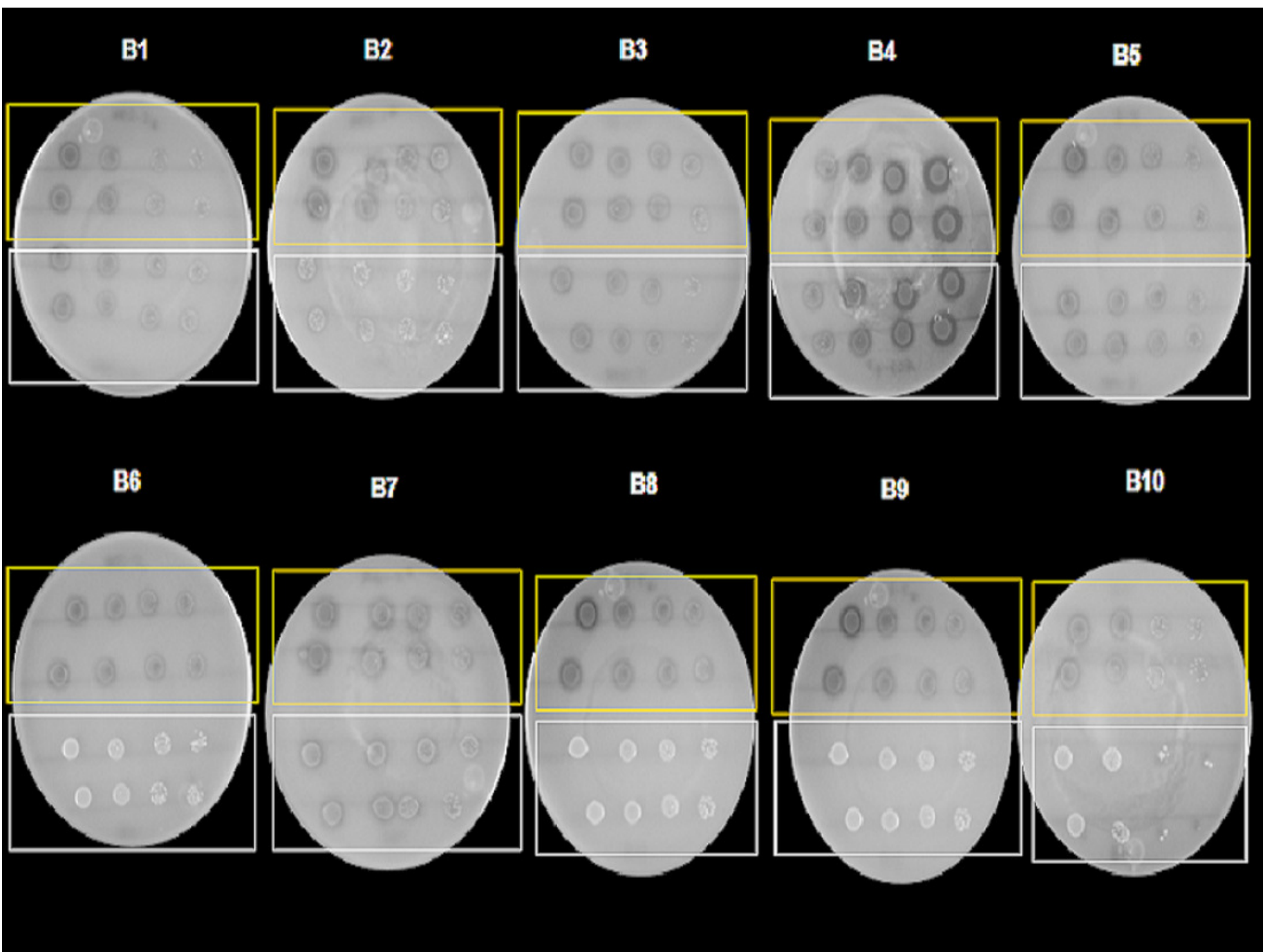


Figure 2

Specific chitinolytic activity of the selected strains.

Values with the same letters $(A, B$ or $C)$ are significantly similar $(P>0.05)$.

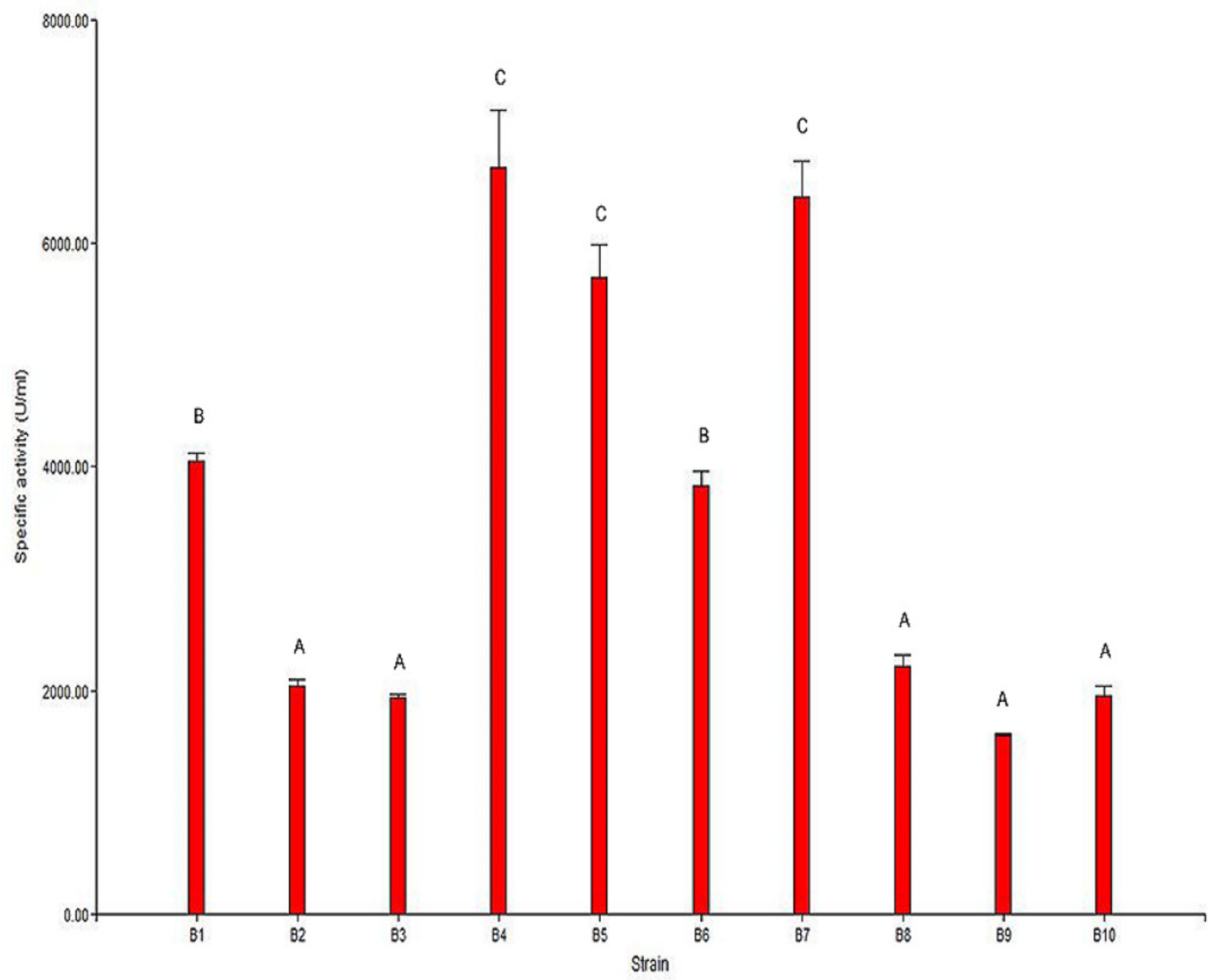


Figure 3

Phylogenetic tree of the selected strains B1 to B9 and the reference strains constructed using the Maximum Likelihood algorithm.

Phylogenetic tree of the selected strains B1 to B9 and the reference strains constructed using the Maximum Likelihood algorithm.

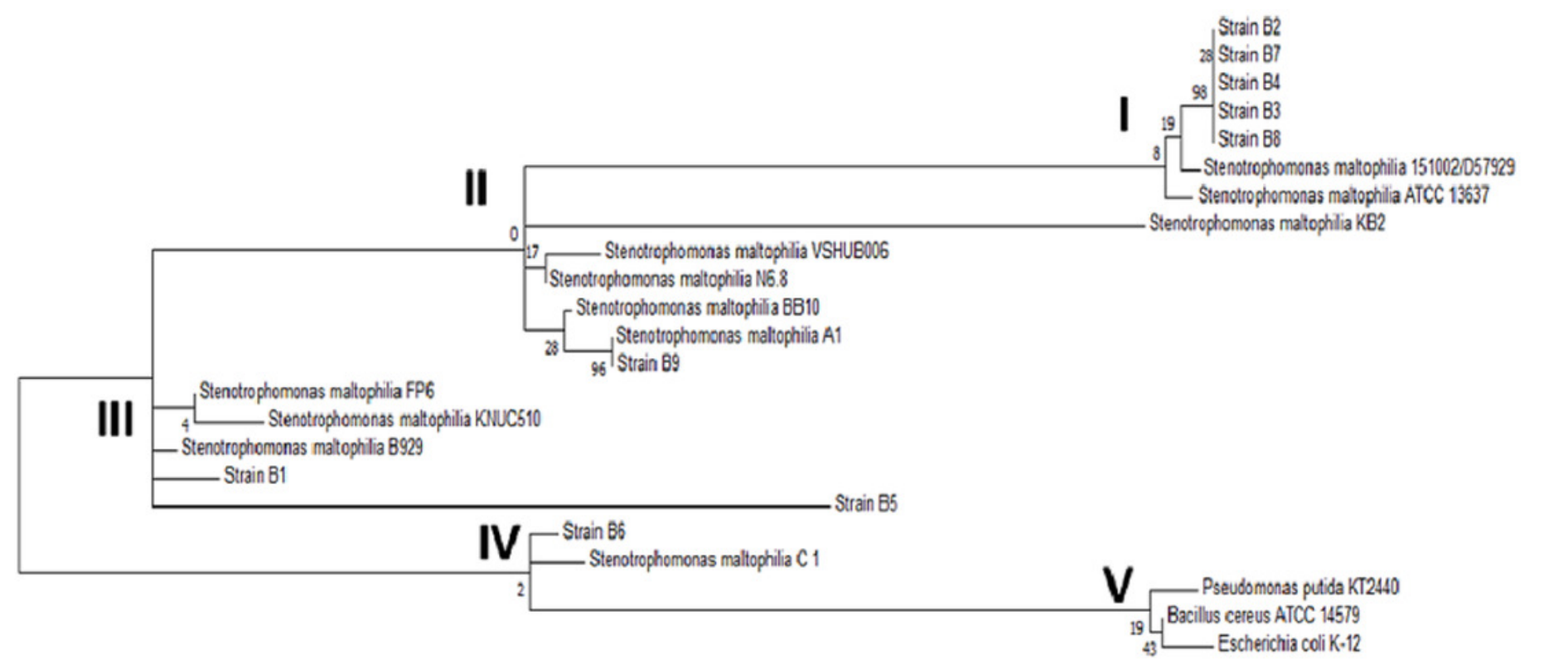

